\title{
Preservation, Reconstruction or Conversion - Contemporary Challenge for Historic Urban Areas and Historic Buildings
}

\author{
BRADECKI Tomasz ${ }^{1, a^{*}}$, UHEREK-BRADECKA Barbara ${ }^{2, \mathrm{~b}}$
}

\author{
${ }^{1,2}$ Akademicka 7, Faculty of Architecture, Silesian University of Technology, Gliwice 44-100 Poland \\ atomasz.bradecki@polsı.pl, bbarbara.bradecka@polsı.pl
}

Keywords: historic buildings, historic urban area, reconstruction, conversion

\begin{abstract}
The problem of preservation, reconstruction and conversion of historic urban layouts and historic buildings have been discussed in the article. Although some of the urban layouts and structures are not monuments by formal means, they are often being well protected by local law (Local Development Plans). Both the quantity of the original structures (very few remained original - many objects within the layout have been already converted) and the quality of the original substance and architectural layout - to little space, many elements which need reconstruction - allow to raise a question: Does preservation or reconstruction still make sense, and does conversion should be allowed. Several case studies have been discussed: Wolf's Throat in Gliwice (Glaubenstatt) - urban village layout set up by Germans in 1941, design for house conversion in Wolfsthroat and also Szobiszowice (Schobischowitz) in Gliwice - one of the urban neighborhoods layout set up by Germans before the II-nd world. Authors of the article are practicing architects: theory versus practice have been discussed.
\end{abstract}

\section{Introduction}

Some of the historic urban districts remain heritage that should be preserved. Examples of spaces that need to be protected are usually historic city centers: most of their historic urban layout with its architecture: old buildings in different styles from different times represent great value.

However some of the urban districts are well defined, there are also urban districts that are extraordinary but do not play a major role in cities urban layout. And so the importance of that in the city scale might be missed. Also architectural features of some of the buildings allow for rising questions: Does conservatory protection make sense, and does preservation or reconstruction still make sense, and does conversion or demolition should be allowed?

In this paper two case studies have been described: both are examples of heritage that need intervention, but no simple choice is obvious to be decided while local law plays a major role for its future. A proposal for systematic qualitative and quantitative feature assessment tool has been presented for better understanding of the problem.

\section{Theoretical Approach}

Many great examples of protected urban districts are well recognized in Europe [1] Most of them are historic centers sided by the line of city walls and most of European cities with medieval origin have them. Historic buildings of great value are mostly listed and protected by local law, but still only those which are characteristic and original for the time, that it was built (according to the International Charter for the Conservation and Restoration of Monuments and Sites - THE VENICE CHARTER 1964) [2]. However there are also urban districts or sites that original design is not that old and also represent great value for today. Good examples might be: Welwyn city and Letchworth city keep their urban layout of garden cities (idea proposed by Ebenezer Howard in 1902). Although the urban layout is protected conservatory area, not all of the buildings are listed. There are also other realizations such as Falkenberg in Germany planned by Bruno Taut, started in 1912 - which is on UNESCO list. 
Heritage is non-renewable in nature, 'an approach to conservation that preserves the best of the heritage but does so without imposing insupportable costs and which affects a rational balance between conservation and change [3]. Many housing settlements represent great value and are part of our heritage but they are not monuments as other public buildings do. Some exceptional single family houses became monuments (such as house over the waterfall by Frank Lloyd Wright or villa Tugenhat in Brno by Mies van der Rohe) but that still is rather unusual. There are also many examples in f.e. Old Workers' Estates in Upper Silesia in Poland, but still proper preservation and revitalization of residential areas and buildings is determined by several means and not only by mean of technical renovation [4].

Most of different historical sites need special approach, and that can be done in appraisals. There are different ways of sites description, however there are common aspects that can be taken into account. A good example might be a proposal by English Heritage which underlines: Location and setting, Historic Development, Architectural Quality and Built Form, Open Space, Parks, Gardens and Trees, Character Zones, Positive Contributors, Locally Important Buildings [5]. Good research and honest appraisal may be helfpful in provision of truly sustainable urban regeneration, that should 'bring about a lasting environment in the economic, physical, social and environmental condition of an area' [6].

\section{Introduction to Gliwice}

As Koshar [7] proves over the course of the twentieth century, Germans have venerated and maintained a variety of historical buildings and urban districts. Monuments and conservation were as important as German approach to monument conservation and design for new buildings and urban districts. And so it was in south Poland: since XVIIth century different parts of the region Silesia belonged to Germany, Austria and Poland depending on time and shape of states' borders.

Gliwice, one of the cities in Silesia is medium size city with ap 180.000 inhabitants located in the south of Poland. It's origins date from XIIIth century. Gliwice have original medieval oval sized centre and it played and was surrounded by city walls which has been preserved till today. Some parts of city walls are still kept and are being protected. The medievial urban layout with characteristic round shape in the core is being protected by Local Development Plan as Conservatory Area: which means that special regulations for possible convertions or new design are set. There four ways of protecting buildings in Poland: an object might be listed in the register of monuments, acknowledgment as a historical monument, the establishment of cultural park or establish protection requirements in the development plan.

\section{The Case Study of Wolf's Throat}

Wilcze Gardło (Wolf's Throat) in Gliwice (Glaubenstatt) is an urban village layout set up by Germans in 1937-1941. Original urban layout has been designed by Rudolf Fischer in the village called Smolnica (Smolnitz) near the woods. It coverd almost 67 ha. Originally the estate was destinated for NSDAP, SA and SS nazi special forces. In 1939 only 26 inhabitants were there but over 1500 in 1961 and later on. Original design refers to old german village, but it has never been finished as planned. In 1975 it has been attached to Gliwice city and so it is till today. The main axis - Traktorzystów street leads to market place, surrounded by multifamily buildings. The basic built structure consist of semidetached houses set on plots of 1000-1300 sqm size. The plots are located in radial layout starting from the market place up to the playground area [8]. Entire village is protected by Local Law (Local Development Plan) and every new project for convertion, renewal or new building must obey those regulations and must be approved by local consevatory. 


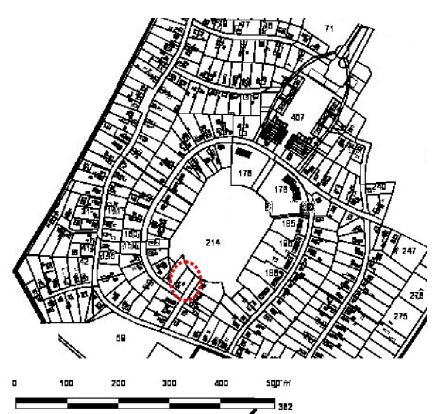

Fig. 1 Wilcze Gardło - Wolf's Throat in Gliwice (Glaubenstatt) - urban layout - location of the plot has been marked; source: Municipal geoinformation system: http://msip-mapa.um.gliwice.pl/
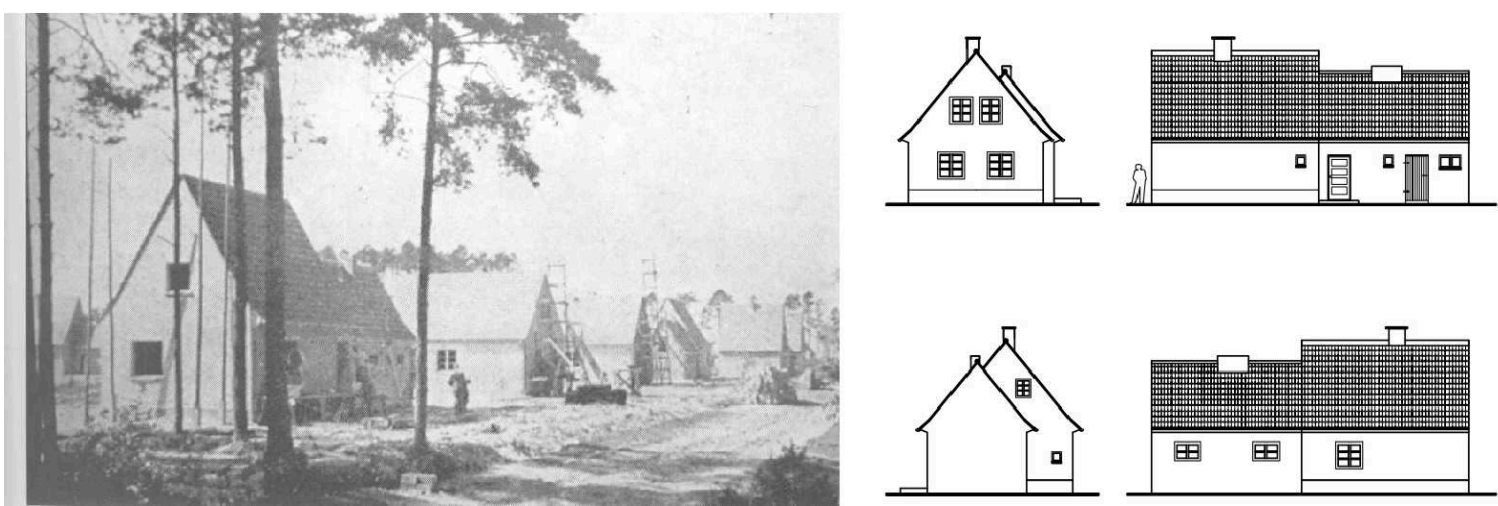

Fig. 2 Wilcze Gardło - Wolf's Throat - typical house [8]

There were 4 different types of houses characteristic for the site: all of them had pitched roof with barely no detail. Part of the building had sloping roof on one side and there were bathroom or kitchen with entrance zone.
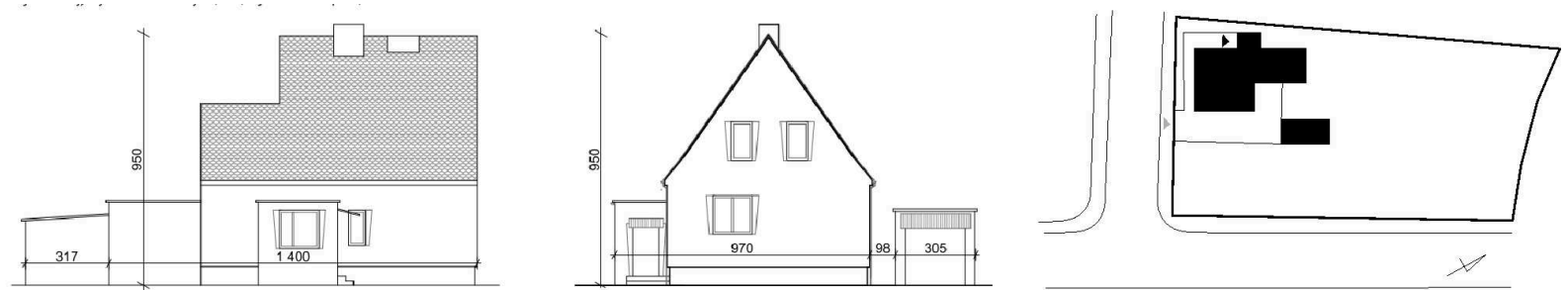

Fig. 3 Single Family House by Magnolii street - existing house; image by Tomasz Bradecki

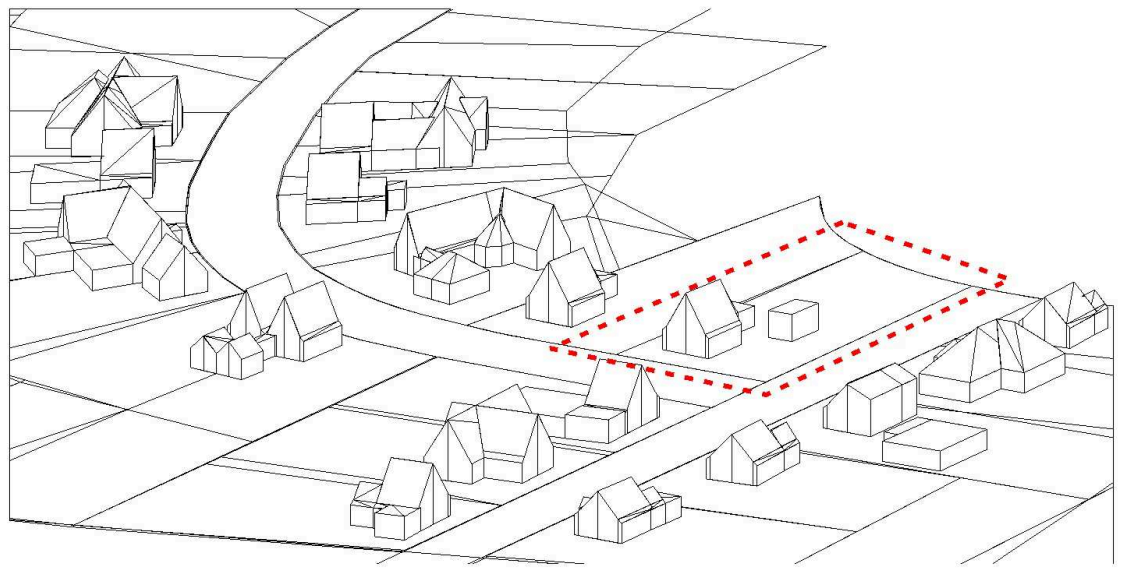

Fig. 4 Axonometric view - the plot marked and close neighbourhood; image by Tomasz Bradecki

The appraisal for the Wolf's Throat housing area has been presented in Table 1. 
Tab. 1 Conservation area appraisal for Wolf's Throat in Gliwice case study - on the basis of English Heritage appraisal [5]

\begin{tabular}{|l|l|l|}
\hline & aspect & commentary \\
\hline 1 & Location and setting & $\begin{array}{l}\text { Area, that is located in long distance to historic center } \\
\text { of the Gliwice city; remains housing area on the } \\
\text { outskirts of the city }\end{array}$ \\
\hline 2 & Historic Development & $\begin{array}{l}\text { Urban layout planned and built at one time; } \\
\text { characteristic for one period }\end{array}$ \\
\hline 3 & $\begin{array}{l}\text { Architectural Quality and Built } \\
\text { Form }\end{array}$ & $\begin{array}{l}\text { Dense built form, average architectural quality, } 4 \text { types } \\
\text { of houses }\end{array}$ \\
\hline 4 & $\begin{array}{l}\text { Open Space, Parks, Gardens } \\
\text { and Trees }\end{array}$ & Soccer playground and open space in conservation area \\
\hline 5 & Character Zones & $\begin{array}{l}\text { Main axis with characteristic buildings, buildings' } \\
\text { location on the plot and plot layout, street layout }\end{array}$ \\
\hline 6 & Positive Contributors & $\begin{array}{l}\text { Front elevations and houses' front: including fence } \\
\text { type, elevation materials }\end{array}$ \\
\hline 7 & Locally Important Buildings & $\begin{array}{l}\text { Buildings that start and close the axis of the urban } \\
\text { layout }\end{array}$ \\
\hline
\end{tabular}
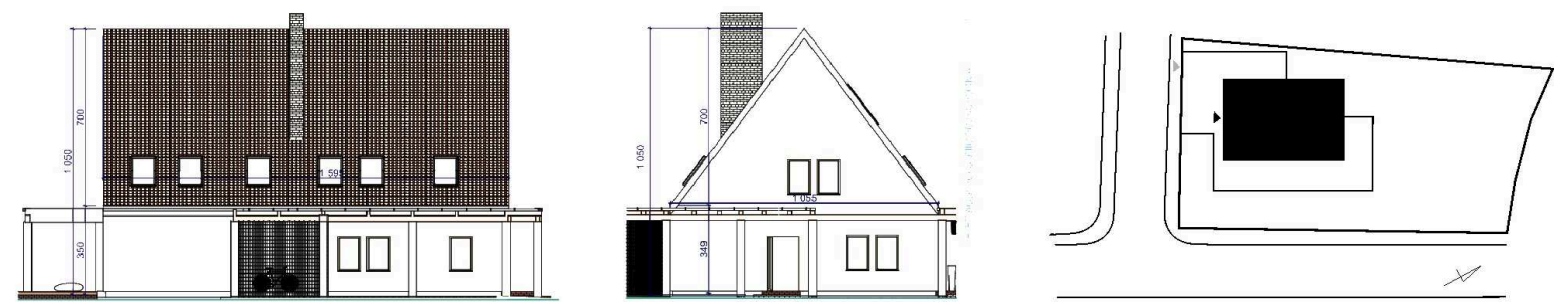

Fig. 5 Single Family House by Magnolii street - design; drawing by Tomasz Bradecki
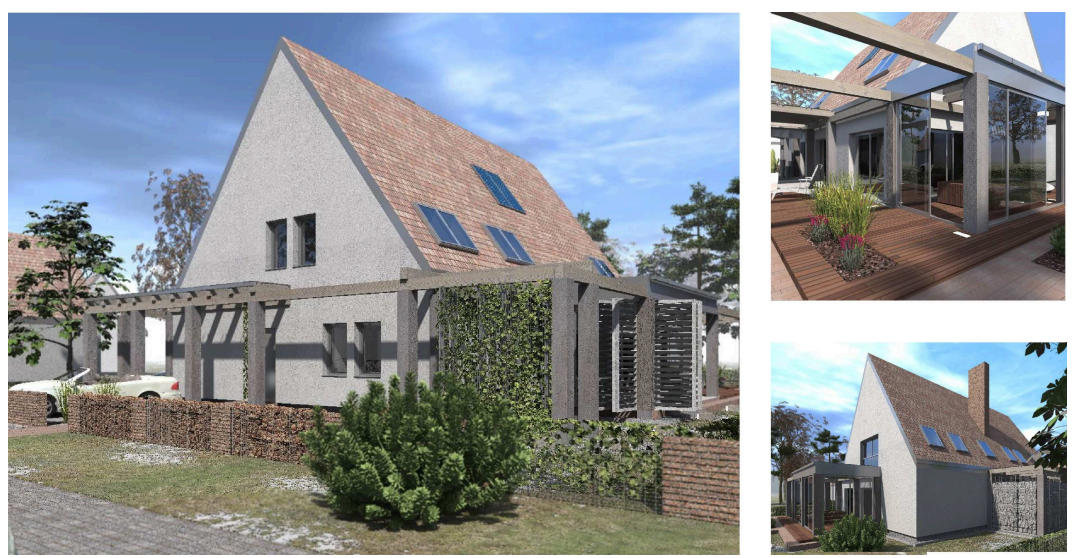

Fig. 6 Single Family House by Magnolii street - design; drawing by Tomasz Bradecki

As the structural elements of the house are in bad condition (old brick, humidity) and so the design proposal suggested by the authors was to rebuilt the house in a form that resembles the existing. The design layout was a slightly bigger house located in same place on the plot as existing one, with pitched roof of the same angle, with roof overhang on the same height. The exterior materials proposal: roof tile and render were the same type and color as in the existing building. Also the size of the windows were narrowed to resemble the historic size. Although the design meets all that criteria, there is no simple decision: local conservatory decided, that according to the LDP [10] only reconstruction of the building means rebuilding it with the exact elevation width, roof height etc. and all parameters as the existing one. If we consider contemporary standards for rooms number size and basic need for total area 100-120 sqm as minimum in single family house - it exceeds the historic layout. 
This case study shows, that setting conservatory standards and strict local law (LDP) may not always be successful solution. The plan allows only for building extension to the back side of the plot in its irrational scale and form which does not allow for design of the standard room size. Authors believe that design proposal is a good compromise and such concept would fit into historic urban layout even thought it is not reconstruction or preservation scheme.

\section{The Case Study of Szobiszowice}

Szobiszowice (Schobischowitz) in Gliwice - one of the urban neighbourhoods layout set up by Germans before the II-nd world next to Nord housing estate. Originally (Petersdorf, Sobischowitz) it used to be a village next to Gliwice and it became a part of the city in 1875 . Some of the housing estates that were set on outskirts of Gliwice were designed in 1939-1944 period and were build for german workers or military forces. Szobiszowice are well known because of the historic radio tower, that has been built in 1934. One of the World War II starting incidents happened there: the false flag operation was performed by Nazi forces; today it is the tallest wooden tower in Europe.

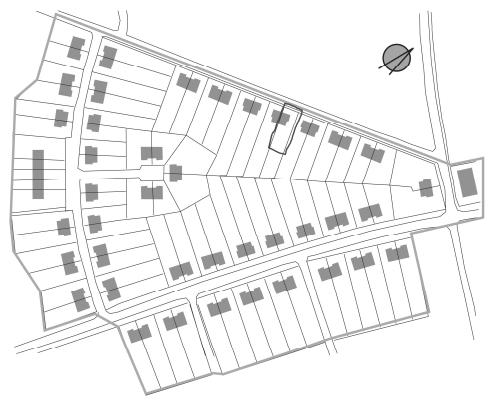

Fig. 7 Szobiszowice (Schobischowitz) in Gliwice - location of the plot has been marked [1]

The housing estate located on aproximately 6ha site is sided by 3 different streets: Lubliniecka street, Polna Street, and $\mathrm{Na}$ Miedzy street (see Fig. 7). The triangle shaped layout has an axis with cul de sac which serves as the finish for Na Miedzy street. There were two typical semi detached house layouts characteristic for the site (see Fig. 8). However many of the buildings has already been rebuild with extension or converted with different architectural style and manner. Some of the extensions are visible from the front and change the original architecture of the building dramatically (see Fig. 9.). Original buildings are very small for contemporary standards (one half provides ap. $70 \mathrm{sqm}$ ) with relatively packed functional programme: small kitchen and toilet, living room and also very small area in bedroom on the second floor.
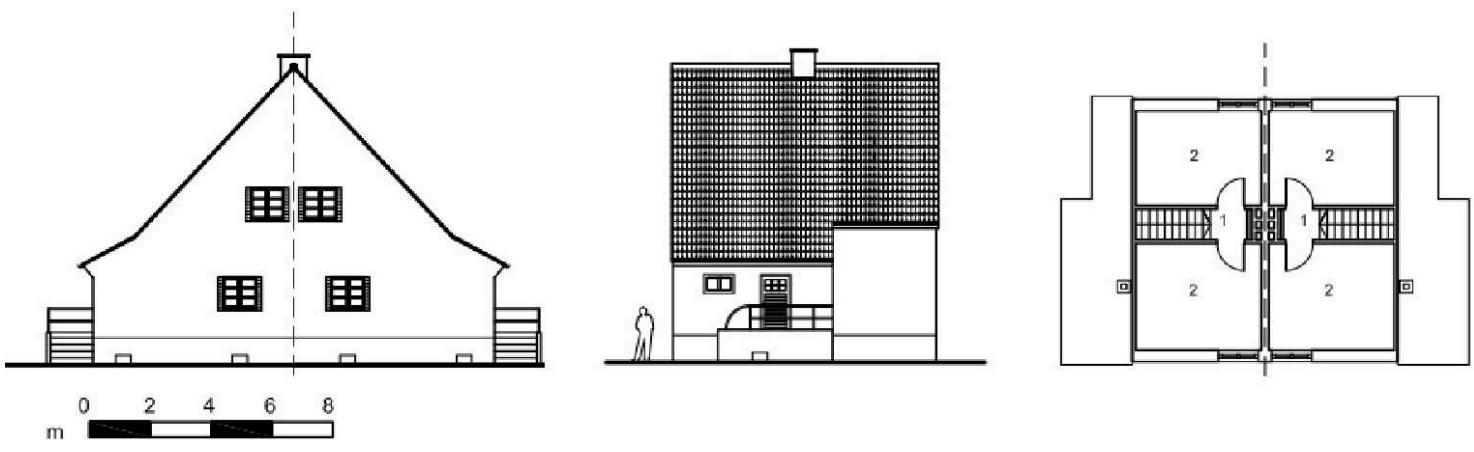

Fig. 8 One of the typical housing layouts in Szobiszowice; semidetached house

The appraisal for the housing area Lubliniecka, Polna, and Na Miedzy street has been presented in Table 2. 
Tab. 2 Conservation area appraisal for Polna street 30 case study - on the basis of English Heritage appraisal [5]

\begin{tabular}{|l|l|l|}
\hline & aspect & commentary \\
\hline 1 & Location and setting & $\begin{array}{l}\text { Area, that is not located close to historic center of the } \\
\text { Gliwice city; remains housing area in the city }\end{array}$ \\
\hline 2 & Historic Development & $\begin{array}{l}\text { Urban layout planned and built at one time; characteristic } \\
\text { for one period }\end{array}$ \\
\hline 3 & $\begin{array}{l}\text { Architectural Quality and Built } \\
\text { Form }\end{array}$ & $\begin{array}{l}\text { Dense built form with high density, average architectural } \\
\text { quality, two types of houses }\end{array}$ \\
\hline 4 & $\begin{array}{l}\text { Open Space, Parks, Gardens } \\
\text { and Trees }\end{array}$ & $\begin{array}{l}\text { Park and open space close to area but no open space in } \\
\text { research area }\end{array}$ \\
\hline 5 & Character Zones & Cul de sac are, and plot layout \\
\hline 6 & Positive Contributors & $\begin{array}{l}\text { Front elevations and housess' front: including fence type, } \\
\text { elevation materials }\end{array}$ \\
\hline 7 & Locally Important Buildings & Buildings that start and close the axis of the urban layout \\
\hline
\end{tabular}

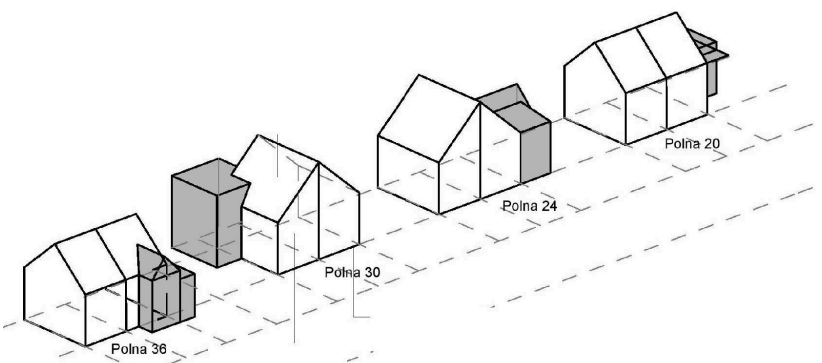

Fig. 9 Polna street axonometric view with the same housing types but every single one with different extension attached since 1990 and Polna 30 case study with extension proposal by authors

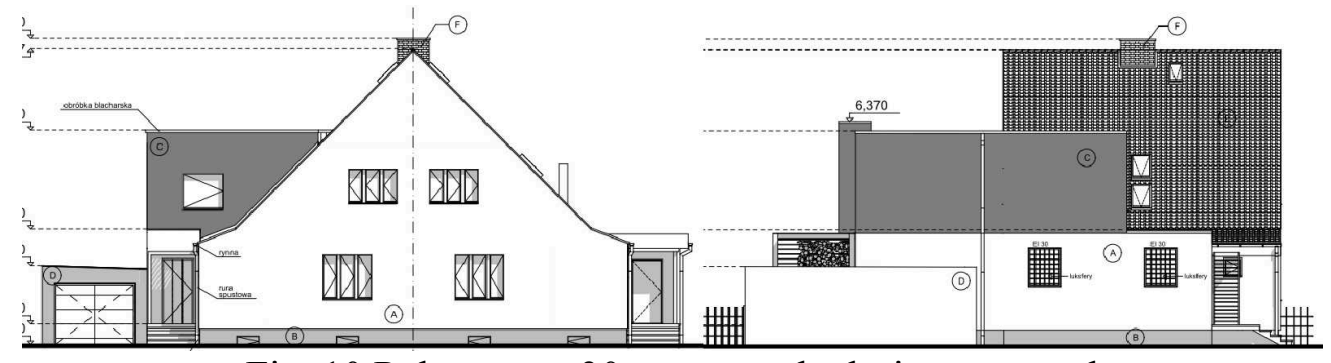

Fig. 10 Polna street 30 - case study design proposal
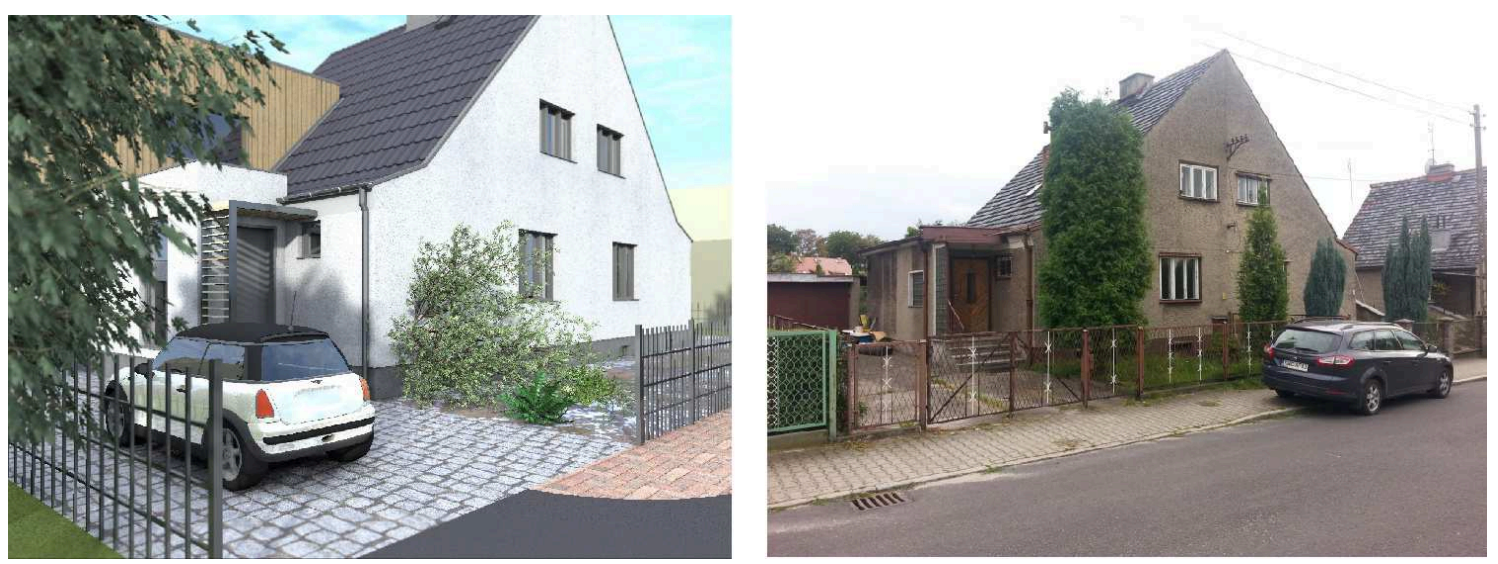

Fig. 11 Polna street 30 - case study design proposal and existing building 
Design proposal suggested by the authors (see Fig. 10 Fig. 11) was adding a simple new form to existing one, but with no interference from the front. The LDP[11] allowed for such a solution and the project has been approved by local authorities and is under construction. However the conservatory policy set in local law was not obvious and easy to interpret and so special consultations were necessary. This case study shows, that contemporary solutions might be mixed with historical approach and still remain in harmony. Authors believe that this is a good example of a conversion of historic building which meets the conservatory standards.

\section{Summary}

Both design proposals presented in the article can be an example of an attempt how to compromise conservatory standards, local law and real needs. Although conservatory standards should play a major role in contemporary development, they must be faced with basic life standards which have changed over time. To strict policies will neither help to keep or protect the buildings which are not exceptional and won't become monuments. Therefore individual approach to every single case study is essential to provide reasonable and sustainable development for areas of great value.

\section{References}

[1] F. W. Carter Conservation, Problems of Historic Cities in Europe. Seminar paper 39. London: UCL, Department of Geography (1981)

[2] http://www.icomos.org/charters/venice_e.pdf

[3] J. Delafons, Politics and Preservation: A Policy History of the Built Heritage, 1882-1996. Front Cover. Taylor \& Francis, (1997)

[4] A. Sulimowska-Ociepka, Industrial heritage in the landscape of the Upper Silesian Agglomeration Central Europe towards Sustainable Building 2013 http://cesb.cz/cesb13/proceedings/2_industrial/CESB13_1233.pdf

[5] English Heritage 'Understanding Place: Conservation Area Designation, Appraisal and Management' 2012.06 http://www.welhat.gov.uk/CHttpHandler.ashx?id=1794\&p=0

[6] P. Roberts et al., The Evolution, Definition and Purpose of Urban Regeneration in. P. Roberts and H. Sykes (eds), Urban Regeneration: a Handbook. London: SAGE Publications

[7] R. Koshar, Germany's Transient Pasts: Preservation and National Memory in the Twentieth Century: Preservation and National Memory in the Twentieth Century, Univ of North Carolina Press, Nov 1, 2000

[8] A. Bednarski, Architektura jednorodzinnych zespołów mieszkaniowych w Gliwicach z lat 1919-1939. Gliwice: Muzeum w Gliwicach, s. 161-162 (2007)

[9] Information on Local Development Plans in Gliwice http://bip.gliwice.eu/strona=10183

[10] Local Development Plan for Wolf's Throat by Authority of Gliwice http://bip.gliwice.eu/pub/uchwaly/9806.pdf

[11] Local Development Plan for Szobiszowice by Authority of Gliwice http://bip.gliwice.eu/pub/uchwaly/10601.pdf 